\title{
Pertumbuhan dan Produksi Beberapa Kultivar Padi Lokal Kalimantan
}

\section{The Growth and Production of Some Local Rice Cultivars from Kalimantan}

\section{Kistia Arinta dan Iskandar Lubis*}

Departemen Agronomi dan Hortikultura, Fakultas Pertanian, Institut Pertanian Bogor (Bogor Agricultural University), Jalan Meranti, Kampus IPB Darmaga, Bogor 16680, Indonesia

Telp. \& Faks. 0251-8629353 e-mail: agronipb@indo.net.id

*Penulis untuk korespondensi : iskandarlbs@yahoo.com

Disetujui 14 Mei 2018 / Published online 21 Mei 2018

\begin{abstract}
This research aims to determine the growth and production of some local rice cultivars of Kalimantan. The research was conducted in November 2015 to May 2016 at Sawah Baru Experimental Field, Institut Pertanian Bogor. A randomized complete block design was used with single factor that was cultivar and three replications. The local rices used in this research are cultivar Abung, Mayas, Samarindah, and Timur with comparison cultivars are Jatiluhur and IPB 8G. The results showed that cultivars treatment significantly affect the growth and production of rices. Cultivar that has the highest productivity and the lowest empty grain among local Kalimantan cultivar is Samarindah.
\end{abstract}

Keywords: growth, local rice, productivity

\begin{abstract}
ABSTRAK
Penelitian ini bertujuan untuk mengetahui pertumbuhan dan produksi beberapa kultivar padi lokal Kalimantan. Penelitian dilaksanakan pada bulan November 2015 hingga Mei 2016 di Kebun Percobaan Sawah Baru, Institut Pertanian Bogor. Rancangan yang digunakan adalah rancangan kelompok lengkap teracak satu faktor yaitu kultivar dengan 3 ulangan. Padi lokal yang digunakan dalam penelitian ini adalah kultivar Abung, Mayas, Samarindah, dan Timur dengan kultivar pembanding yaitu Jatiluhur dan IPB 8G. Hasil penelitian menunjukkan bahwa perlakuan kultivar berpengaruh nyata terhadap pertumbuhan dan produksi padi. Kultivar yang memiliki produktivitas tertinggi dan persentase gabah hampa per malai per rumpun terendah diantara kultivar lokal Kalimantan adalah Samarindah.
\end{abstract}

Kata kunci: padi lokal, pertumbuhan, produktivitas 


\section{PENDAHULUAN}

Pemenuhan kebutuhan beras di Indonesia dilakukan dengan peningkatan produksi dalam negeri dibantu dengan kebijakan impor beras yang dilakukan oleh pemerintah Indonesia. Data yang diperoleh dari BPS (2015) menerangkan bahwa pemerintah melakukan impor beras dari berbagai negara sebesar $844.163,7$ ton atau senilai US\$ $388.178,5$ juta pada tahun 2014. Besarnya impor beras dapat disebabkan oleh besarnya perubahan fungsi lahan dari pertanian ke non pertanian. Selain itu, permasalahan yang terjadi akhir-akhir ini adalah perubahan cuaca yang tidak dapat di prediksi seperti musim kering yang lebih panjang sehingga terjadi gagal panen atau gagal tanam. Permasalahan tersebut dapat diatasi dengan cara meningkatkan produksi padi per satuan luas dengan salah satunya penggunaan varietas unggul yang berdaya hasil tinggi, atau dengan penanaman padi gogo di lahan kering.

Penggunaan varietas unggul secara tidak langsung menggeser keberadaan padi lokal yang memiliki kualitas tinggi seperti rasa pulen dan aromatik. Hasil eksplorasi yang dilakukan Nurhasanah dan Sunaryo (2015) memperoleh 44 kultivar padi lokal yang terdiri dari 39 kultivar padi beras dan 5 kultivar padi ketan dari sebelumnya terdapat 103 kultivar. Menurut Nurhasanah dan Sunaryo (2015) berkurangnya keragaman genetik padi lokal di Kabupaten Kutai Barat Kalimantan Timur mungkin dikarenakan peralihan pilihan petani dari menanam kultivar lokal menjadi varietas unggul nasional yang cenderung memiliki umur tanam yang relatif cepat serta berdaya hasil tinggi setelah munculnya revolusi hijau. Padi lokal merupakan sumber genetik yang potensial untuk dimanfaatkan dalam perakitan varietas baru. Umumnya padi lokal yang ditanam di lahan pasang surut dan lahan sawah memiliki tekstur nasi sedang sampai pera. Padi Mayas adalah salah satu kultivar padi gogo lokal kalimantan (Kaltimprov.go.id, 2013). Kultivar padi lokal Kalimantan Timur ini memiliki beberapa sifat keunggulan yaitu kualitas rasa yang tinggi dan tahan terhadap cekaman lingkungan abiotik (Subroto, 2002). Pemulia dapat mengambil sifat baik dari padi gogo lokal Kalimantan ini dan menggabungkannya dengan tetua lain agar dapat menghasilkan verietas baru yang memiliki daya hasil tinggi serta kualitas beras yang baik.

Berdasarkan informasi diatas maka padi lokal Kalimantan ini perlu dilestarikan dan dikembangkan agar plasma nutfah yang ada tidak hilang. Penelitian ini bertujuan untuk mengetahui perbedaan pertumbuhan dan produksi beberapa kultivar padi lokal Kalimantan.

\section{BAHAN DAN METODE}

Penelitian ini dilaksanakan di Kebun Percobaan IPB Sawah Baru, Darmaga, Bogor Departemen Agronomi dan Hortikultura, IPB. Pengukuran biomassa dilakukan di Laboratorium Pasca Panen, Departemen Agronomi dan Hortikultura IPB. Penelitian berlangsung pada bulan November 2015 hingga Mei 2016. Rancangan percobaan yang digunakan adalah Rancangan Kelompok Lengkap Teracak (RKLT). Percobaan ini terdiri dari 6 kultivar dan 3 ulangan sehingga didapatkan 18 satuan percobaan dengan luas masing-masing petak adalah $20 \mathrm{~m}^{2}$. Penelitian ini menggunakan benih yang berasal dari 4 kultivar lokal Kalimantan dan 2 kutivar pembanding. 4 kultivar lokal tersebut antra lain: Abung, Mayas, Samarindah dan Timur. 2 kultivar pembanding yaitu kultivar Jatiluhur, dan IPB 8G. Alasan penggunaan 2 kultivar pembanding ini karena kultivar Jatiluhur merupakan kultivar unggul lama dan kultivar IPB 8G adalah kultivar padi tipe baru. Pupuk yang digunakan adalah Urea, SP-36 dan KCl. Alat yang digunakan dalam penelitian ini adalah seperangkat alat budidaya tanaman, oven, ember, timbangan analitik, Leaf Area Meter LI 3000C, meteran, kamera, alat tulis, dan SPAD meter.

Pelaksanaan penelitian dimulai dengan pengolahan lahan sebanyak 2 kali dengan pembajakan dan penggaruan. Pengolahan pertama dilakukan 2 minggu sebelum tanam dan pengolahan kedua 1 minggu sebelum tanam. Padi ditanam dengan sistem tanam benih langsung, jarak tanam yang digunakan adalah $50 \mathrm{~cm} \times 10$ $\mathrm{cm}$. Penanaman dengan cara menugal pada kedalaman sekitar 3-5 cm dengan jumlah benih 5 butir per lubang tanam. Penyulaman dilakukan pada saat 2 MST. Penyiraman dilaksanakan dengan mempertimbangkan kondisi cuaca. Pengendalian hama dilakukan dengan melakukan pengontrolan secara rutin terhadap gejala-gejala serangan yang terjadi di lapangan. Pemupukan tanaman padi dilakukan 3 kali selama musim tanam. Pupuk yang digunakan antara lain: Urea dengan dosis $150 \mathrm{~kg} \mathrm{ha}^{-1}, 75 \mathrm{~kg} \mathrm{ha}^{-1} \mathrm{SP}-36,75 \mathrm{~kg}$ $\mathrm{ha}^{-1} \mathrm{KCl}$. Aplikasi pupuk pertama dilakukan pada saat penanaman berupa $1 / 3$ dari dosis urea dan keseluruhan SP-36 dan KCl. Aplikasi kedua pada umur 3 MST adalah dosis $1 / 3$ dari dosis urea. Aplikasi pupuk terakhir pada umur 6 MST dengan dosis pupuk Urea $1 / 3$ dosis dari dosis awal. Padi siap panen sekitar 30 hari setelah berbunga merata, atau ketika $90 \%$ malai dari populasi padi telah berwarna kuning dan merunduk.

Panen dilakukan saat pagi hari. Pengamatan non-destruktif dilakukan pada 10 tanaman contoh 
dan pengamatan destruktif dilakukan pada 2 tanaman contoh untuk setiap satuan percobaan. Peubah yang diamati antara lain: Tinggi tanaman $(\mathrm{cm})$, jumlah anakan per rumpun (batang), luas daun, warna daun menggunakan alat SPAD meter, dan bobot kering tajuk $(\mathrm{g} / \mathrm{tan})$. Pengamatan komponen hasil antara lain: Jumlah anakan produktif, jumlah gabah per malai, jumlah malai per rumpun, panjang malai, bobot 1000 butir gabah bernas, persen gabah hampa, dugaan hasil per hektar dengan menghitung produktivitas ubinan $(1 \mathrm{~m} \times 1 \mathrm{~m})$ yang dikonversikan ke hektar.

Data yang diperoleh dari hasil pengamatan pertumbuhan, komponen hasil, dan hasil padi dianalisis menggunakan uji $\mathrm{F}$ (Analisis ragam). Jika hasil uji $\mathrm{F}$ berpengaruh nyata, maka dilanjutkan dengan uji lanjut Tukey pada taraf $5 \%$.

\section{HASIL DAN PEMBAHASAN}

\section{Kondisi Umum}

Penelitian ini dilaksanakan di Kebun Percobaan Sawah Baru IPB. Berdasarkan data dari BMKG Dramaga Bogor tahun 2016, lokasi penelitian memiliki ketinggian $207 \mathrm{~m}$ dpl. Penelitian dimulai bulan November 2015 hingga Mei 2016. Lahan yang digunakan adalah lahan kering bekas penelitian kedelai yang telah diberakan. Daya tumbuh benih di lapangan cukup tinggi yaitu $90 \%$ akan tetapi terdapat dua petakan yang memiliki daya tumbuh benih kurang dari 90\% sehingga dilakukan penyulaman. Terdapat lebih dari 10 ekor burung turun ke lahan pada sore hari setelah penanaman dilakukan, kemungkinan banyaknya lubang tanam yang tidak ditumbuhi padi dikarenakan benih padi dimakan oleh burung-burung tersebut. Petakan tersebut adalah petak kultivar Mayas ulangan 2 dan kultivar Samarindah ulangan 2.

Tabel 1. Daya tumbuh benih padi di lapangan

\begin{tabular}{lc}
\hline Kultivar & DB $(\%)$ \\
\hline Abung & $91,03 \mathrm{ab}$ \\
Mayas & $87,73 \mathrm{~b}$ \\
Samarindah & $91,30 \mathrm{ab}$ \\
Timur & $92,43 \mathrm{ab}$ \\
Jatiluhur & $95,00 \mathrm{a}$ \\
IPB 8G & $95,77 \mathrm{a}$ \\
\hline Keterangan : & Angka yang diikuti huruf yang sama pada \\
& kolom yang sama tidak berbeda nyata pada \\
& Uji Tuckey traf 5\%
\end{tabular}

Penyulaman dilakukan selama satu minggu. Kondisi pertanaman pada minggu pertama sudah tumbuh diiringi dengan tumbuhnya gulma, penyiangan gulma dilakukan pada minggu ke- 2 .
Hama pertama yang ditemukan adalah belalang (Melanoplus femurrubrum) tergolong famili Acrididae yang merusak pertanaman padi dengan cara memakan batang tanaman padi pada bagian pangkal batang. Pengendalian hama dilakukan dengan menyemprotkan insektisida berbahan aktif Fipronil $50 \mathrm{~g} / \mathrm{l}$ pada saat 4 MST. Ditemukan bangkai dari belalang (Melanoplus femurrubrum) yang cukup banyak pada minggu ke 5 dan 6 . Tanaman mulai terlihat terserang cendawan Pyricularia orizae pada minggu ke-6 dengan gejala bercak coklat pada daun yaitu pada kultivar Samarindah dan Timur. Upaya yang dilakukan untuk mengendalikan bercak daun ini dengan menyemprotkan fungisida berbahan aktif Difenokonasol 250g/l.

Serangan penggerek batang ditemukan pada minggu ke-7 dengan gejala daun muda menggulung dan berwarna kuning, setelah diidentifikasi ditemukan ulat berukuran kecil serangan hama tersebut biasa disebut dengan sundep. Hama tersebut dikendalikan dengan insektisida berbahan aktif Dimehipo $400 \mathrm{~g} / \mathrm{l}$. Walang sangit (Leptocorisa oratorius) menyerang tanaman padi pada saat tanaman mulai berbunga hingga 2 MST setelah berbunga sehingga mengakibatkan bulir gabah menghitam dan kosong. Serangan hama lainnya adalah burung pipit (Lonchura leucogastroides) pada stadia masak susu, burung memakan biji padi dan hinggap diatas malai sehingga membuat bulir padi kosong dan patah. Hama burung tersebut dikendalikan dengan pemasangan jaring pada pinggir dan atas pertanaman. Serangan burung pipit terbesar pada kultivar Abung dan IPB 8G kemungkinan terdapat karakter morfologi tanaman yang mendukung parahnya serangan tersebut. Kerebahan terjadi pada kultivar Jatiluhur. Seluruh ulangan pada kultivar Jatiluhur secara bertahap mengalami kerebahan. Kerebahan juga dialami oleh kultivar IPB 8G. Kemungkinan terdapat presentase gabah hampa yang besar pada kultivar IPB 8G dikarenakan kerebahan ini.

\section{Vegetatif Tanaman Padi}

\section{Tinggi Tanaman}

Berdasarkan data hasil pengamatan yang diperoleh selama penelitian, perlakuan kultivar nyata berpengaruh terhadap tinggi tanaman. Analisis sidik ragam menunjukkan bahwa perlakuan kultivar berpengaruh nyata terhadap tinggi tanaman pada umur 9, 10 dan 13 MST dan sangat nyata pada umur 2 MST. Rataan tinggi tanaman pada umur 2, 9, 10 dan 13 MST disajikan dalam Tabel 2. 
Tabel 2. Rata-rata tinggi tanaman padi pada 2, 9, 10, 13 MST

\begin{tabular}{lcccc}
\hline \multicolumn{1}{c}{ Kultivar } & \multicolumn{4}{c}{ Tinggi tanaman pada.. (cm) } \\
& $2 \mathrm{MST}$ & $9 \mathrm{MST}$ & $10 \mathrm{MST}$ & $13 \mathrm{MST}$ \\
\hline Abung & $18,63 \mathrm{ab}$ & $101,18 \mathrm{a}$ & $110,89 \mathrm{ab}$ & $123,83 \mathrm{ab}$ \\
Mayas & $17,07 \mathrm{~b}$ & $99,57 \mathrm{a}$ & $108,83 \mathrm{ab}$ & $114,97 \mathrm{~b}$ \\
Samarindah & $17,51 \mathrm{ab}$ & $114,22 \mathrm{a}$ & $125,37 \mathrm{a}$ & $135,93 \mathrm{a}$ \\
Timur & $20,74 \mathrm{a}$ & $112,17 \mathrm{a}$ & $122,40 \mathrm{ab}$ & $134,63 \mathrm{ab}$ \\
Jatiluhur & $20,17 \mathrm{a}$ & $93,37 \mathrm{a}$ & $104,87 \mathrm{~b}$ & $127,77 \mathrm{ab}$ \\
IPB 8G & $20,69 \mathrm{a}$ & $101,32 \mathrm{a}$ & $107,88 \mathrm{ab}$ & $122,80 \mathrm{ab}$ \\
\hline
\end{tabular}

Keterangan: Angka yang diikuti huruf yang sama pada kolom yang sama tidak berbeda nyata pada Uji Tuckey taraf 5\%; MST = Minggu Setelah Tanam.

Data tinggi tanaman padi minggu ke 13 menunjukkan kultivar yang memiliki tinggi tanaman terpendek adalah kultivar lokal Mayas dengan tinggi $114,97 \mathrm{~cm}$ nyata berbeda lebih pendek dari kultivar Samarindah namun tidak berbeda nyata dengan Jatiluhur dan IPB 8G.

Tabel 3 menyajikan data hasil uji lanjut tinggi tanaman pada umur 14 sampai 18 MST.

Tabel 3. Rata-rata tinggi tanaman padi pada 14-18 MST

\begin{tabular}{llllll}
\hline \multirow{2}{*}{ Kultivar } & \multicolumn{4}{c}{ Tinggi tanaman pada.. (cm) } \\
& $14 \mathrm{MST}$ & $15 \mathrm{MST}$ & $16 \mathrm{MST}$ & $17 \mathrm{MST}$ & $18 \mathrm{MST}$ \\
\hline Abung & $129,00 \mathrm{ab}$ & $133,93 \mathrm{ab}$ & $140,07 \mathrm{ab}$ & $140,57 \mathrm{ab}$ & $141,53 \mathrm{ab}$ \\
Mayas & $115,10 \mathrm{~b}$ & $115,03 \mathrm{~b}$ & $116,70 \mathrm{~b}$ & $118,90 \mathrm{~b}$ & $122,13 \mathrm{~b}$ \\
Samarindah & $140,90 \mathrm{a}$ & $146,73 \mathrm{a}$ & $152,43 \mathrm{a}$ & $156,50 \mathrm{a}$ & $161,53 \mathrm{a}$ \\
Timur & $139,37 \mathrm{a}$ & $141,53 \mathrm{a}$ & $146,43 \mathrm{a}$ & $148,47 \mathrm{a}$ & $151,80 \mathrm{a}$ \\
\hline
\end{tabular}

Keterangan: Angka yang diikuti huruf yang sama pada kolom yang sama tidak berbeda nyata pada Uji Tuckey taraf 5\%; MST = Minggu Setelah Tanam.

Tinggi tanaman padi dari kultivar Jatiluhur, Abung, Samarindah dan Timur tergolong dalam kategori tanaman padi yang tinggi, sedangkan kultivar Mayas dan IPB 8G termasuk dalam kategori tanaman padi yang memiliki tinggi sedang, sejalan dengan ketentuan kriteria tinggi pada tanaman padi gogo berdasar pada Rice Standard Evaluation System yaitu agak pendek $(<90 \mathrm{~cm})$, sedang $(90-125 \mathrm{~cm})$, dan tinggi $(>125$ $\mathrm{cm})$ (IRRI, 2002).

Perbedaan tinggi tanaman dapat dikarenakan faktor genetik suatu kultivar. Hal tersebut sejalan dengan pendapat Nazirah dan Damanik (2015) yang menyatakan bahwa perbedaan susunan genetik merupakan salah satu faktor yang menyebabkan penampilan tanaman beragam dalam hal ini adalah tinggi tanaman. Menurut Yunanda et al. (2013) yang menyatakan hasil penelitiannya menunjukkan bahwa sistem budidaya sawah menghasilkan tanaman yang lebih tinggi dari pada sistem budidaya gogo. Menurut Syahri dan Somantri (2013) tinggi tanaman pada tanaman padi dapat digunakan sebagai salah satu parameter pertumbuhan tetapi pertumbuhan tanaman yang tinggi belum menjamin hasil yang diperoleh lebih besar.
Tinggi tanaman pada minggu ke 18 memiliki ratarata 122,13-161,53 cm. Kultivar Samarindah dengan tinggi tanaman rata-rata mencapai $161,53 \mathrm{~cm}$ tidak berbeda nyata dengan kultivar Timur dan Abung. Kultivar dengan tinggi tanaman terpendek adalah Mayas dengan rata-rata tinggi tanaman $122,13 \mathrm{~cm}$ diakhir pengamatan. 
MST dikarenakan umur tanaman yang berbeda. Hasil pengamatan disajikan dalam Tabel 4.

Data menunjukkan rata-rata jumlah anakan pada 10 MST dari ke empat kultivar lokal dan IPB 8G memiliki jumlah anakan rata-rata 12-14 anakan per rumpun. Kultivar Jatiluhur memiliki jumlah anakan terbanyak akan tetapi masih tergolong rendah yaitu 18,50 batang per rumpun atau hampir 4 batang per tanaman jika dibagi dengan jumlah benih yang ditanam yaitu 5 benih. Kultivar lokal Kalimantan memiliki jumlah anakan lebih sedikit dari Jatiluhur yaitu jumlah anakan per batangnya adalah rata-rata hampir 3 anakan. Berdasarkan jumlah anakan yang terbentuk, dapat dikatakan bahwa kultivar yang digunakan dalam penelitian ini memiliki kemampuan beranak sangat rendah sesuai dengan Rice Standard Evaluation System yaitu sangat tinggi (>25 anakan/tanaman), tinggi (20-25 anakan/tanaman), sedang (10-19 anakan/tanaman), rendah (5-9 anakan/tanaman), sangat rendah $\quad(<5$ anakan/tanaman) (IRRI, 2002).

Tabel 4. Rata-rata jumlah anakan padi pada 2 MST, 5-10 MST

\begin{tabular}{llllllll}
\hline \multirow{2}{*}{ Kultivar } & \multicolumn{7}{c}{ Jumlah anakan (batang) } \\
\cline { 2 - 7 } & $2 \mathrm{MST}$ & $5 \mathrm{MST}$ & $6 \mathrm{MST}$ & $7 \mathrm{MST}$ & $8 \mathrm{MST}$ & $9 \mathrm{MST}$ & $10 \mathrm{MST}$ \\
\hline Abung & $4,90 \mathrm{a}$ & $12,67 \mathrm{ab}$ & $14,23 \mathrm{ab}$ & $14,40 \mathrm{ab}$ & $14,47 \mathrm{ab}$ & $14,73 \mathrm{~b}$ & $14,87 \mathrm{ab}$ \\
Mayas & $4,97 \mathrm{a}$ & $11,57 \mathrm{ab}$ & $12,97 \mathrm{~b}$ & $13,63 \mathrm{~b}$ & $14,13 \mathrm{~b}$ & $14,50 \mathrm{~b}$ & $14,87 \mathrm{ab}$ \\
Samarindah & $4,87 \mathrm{a}$ & $9,17 \mathrm{~b}$ & $11,10 \mathrm{~b}$ & $11,43 \mathrm{~b}$ & $11,67 \mathrm{~b}$ & $11,93 \mathrm{~b}$ & $12,03 \mathrm{~b}$ \\
Timur & $4,87 \mathrm{a}$ & $11,63 \mathrm{ab}$ & $13,30 \mathrm{ab}$ & $13,67 \mathrm{~b}$ & $14,07 \mathrm{~b}$ & $14,00 \mathrm{~b}$ & $14,07 \mathrm{~b}$ \\
Jatiluhur & $4,53 \mathrm{~b}$ & $14,90 \mathrm{a}$ & $17,73 \mathrm{a}$ & $18,57 \mathrm{a}$ & $18,97 \mathrm{a}$ & $19,03 \mathrm{a}$ & $18,50 \mathrm{a}$ \\
IPB 8G & $4,87 \mathrm{a}$ & $11,60 \mathrm{ab}$ & $12,77 \mathrm{~b}$ & $13,13 \mathrm{~b}$ & $13,20 \mathrm{~b}$ & $13,17 \mathrm{~b}$ & $12,27 \mathrm{~b}$ \\
\hline
\end{tabular}

Keterangan : Angka yang diikuti huruf yang sama pada kolom yang sama tidak berbeda nyata pada Uji Tuckey taraf 5\%; MST = Minggu Setelah Tanam.

Menurut Cepy dan Wayan (2011) tinggi rendahnya pertumbuhan serta hasil tanaman dipengaruhi oleh 2 faktor yaitu internal yang meliputi sifat genetik atau turunan tanaman dan eksternal yaitu faktor lingkungan seperti iklim tanah dan faktor biotik. Perbedaan jumlah anakan masing-masing kultivar diduga karana pengaruh faktor-faktor tersebut. Hal tersebut sejalan dengan hasil penelitian dari Anhar et al. (2016) yang menyatakan bahwa jumlah anakan dan tinggi tanaman yang berbeda dikarenakan setiap varietas memiliki sifat gen yang berbeda-beda. Sistem tanam langsung menghasilkan anakan yang lebih sedikit dari pada sistem tanam pindah. Anakan tersier tidak begitu diinginkan karena hanya akan menghasilkan pertumbuhan malai yang terlambat masak dan kalah bersaing dengan anakan primer dan sekunder (Manurung dan Ismunadji, 1988).

\section{Bobot Kering Tajuk}

Hasil uji lanjut pengukuran bobot kering tajuk disajikan dalam Tabel 5. Data tersebut menunjukkan pada umur 4 MST kultivar IPB 8G memiliki bobot kering tajuk terbesar dan berbeda nyata dengan kultivar Mayas, namun tidak berbeda nyata dengan kultivar lain. Kultivar Samarindah berbeda nyata memiliki bobot kering tajuk pada saat panen yang nyata lebih besar dibandingkan dengan kultivar Jatiluhur, tetapi tidak berbeda nyata dengan yang lain.

Menurut Prawiranata (1988) berat kering suatu tanaman merupakan hasil penumpukan fotosintat yang dalam pembentukannya membutuhkan unsur hara, air, karbon dioksida dan cahaya matahari. Hasil penelitian yang dilakukan oleh Kurniasih et al. ( 2008) menunjukkan pengaruh yang nyata dari kadar garam terhadap berat kering tajuk tanaman padi. Dan didapatkan bahwa semakin sering tanaman disiram dengan air garam maka berat kering tajuk tanaman akan menurun. Hasil penelitian dari Bustami et al. (2012) mengemukakan bahwa tingginya hasil bahan kering pada 16 dari 50 varietas yang diuji diduga ada hubungannya dengan tinggi tanaman dan jumlah anakan.

Menurut Simangunsong (2013) penumpukan asimilat mulai terjadi sejak inisisasi malai dan mencapai puncaknya pada anthesis dan setelah itu simpanan tersebut berkurang cukup signifikan karena pertumbuhan padi sudah mulai berfokus pada pengisian biji. Hal tersebut berlaku pada penelitian ini ditunjukkan pada Gambar 1 terlihat bahwa terjadi penambahan bobot kering tajuk hingga fase berbunga $50 \%$ kemudian secara signifikan berat kering tajuk berkurang hingga panen. 
Tabel 5. Rata-rata berat kering tajuk pada 4 MST dan saat panen

\begin{tabular}{lcc}
\hline \multirow{2}{*}{ Kultivar } & \multicolumn{2}{c}{ Berat kering tajuk (gram) } \\
\cline { 2 - 3 } & $4 \mathrm{MST}$ & Panen \\
\hline Abung & $0,89 \mathrm{ab}$ & $35,03 \mathrm{ab}$ \\
Mayas & $0,63 \mathrm{~b}$ & $34,50 \mathrm{ab}$ \\
Samarindah & $0,79 \mathrm{ab}$ & $37,41 \mathrm{a}$ \\
Timur & $1,19 \mathrm{ab}$ & $31,97 \mathrm{ab}$ \\
Jatiluhur & $1,46 \mathrm{ab}$ & $21,28 \mathrm{~b}$ \\
IPB 8G & $1,74 \mathrm{a}$ & $31,47 \mathrm{ab}$ \\
\hline
\end{tabular}

Keterangan: Angka yang diikuti huruf yang sama pada kolom yang sama tidak berbeda nyata pada Uji Tuckey taraf 5\%; MST = Minggu Setelah Tanam.

Hasil dari penelitian-penelitian yang telah dilakukan, banyak faktor yang dapat menyebabkan perbedaan respon berat kering tajuk. Berdasarkan grafik rata-rata bobot kering tajuk terdapat dua perlakuan yang tidak mengalami penurunan bobot kering tajuk pada saat panen yaitu kultivar lokal Mayas dan kultivar IPB 8G.

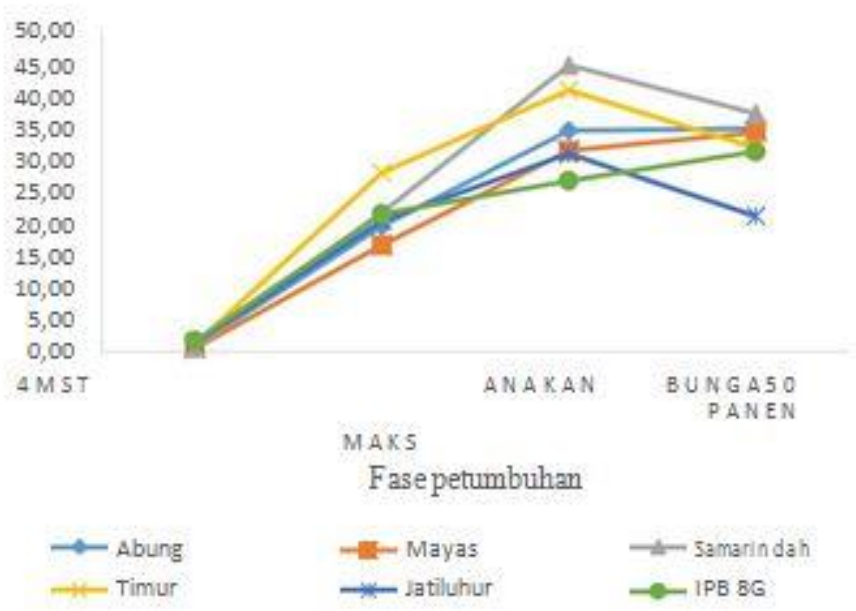

Gambar 1. Grafik rata-rata bobot kering tajuk dari 4 MST hingga panen

Hal tersebut menunjukkan bahwa laju fotosintesis pada kedua perlakuan kultivar tersebut berbeda dengan yang lain. Seperti yang dikemukakan oleh Dwijoseputro (1992) dalam Bustami et al. (2012) bila laju fotosintesis berbeda maka jumlah fotosintat yang dihasilkan juga berbeda, demikian juga berat kering tanaman yang merupakan cerminan dari laju pertumbuhan tanaman.

\section{Luas dan Warna Daun}

Pengukuran luas dan warna daun dilakukan pada fase anakan maksimum dan berbunga $50 \%$. Berdasarkan hasil analisis ragam pada taraf 5\%, perlakuan kultivar nyata berpengaruh terhadap luas dan warna daun. Perlakuan kultivar berpengaruh nyata terhadap luas daun pada fase anakan maksimum dan berpengaruh sangat nyata pada fase berbunga 50\%. Hasil pengukuran luas daun tertera pada tabel 6 .

Kultivar yang memiliki daun terluas pada fase anakan maksimum adalah Timur yaitu $73.71 \mathrm{~cm}^{2}$ dan tidak berbeda nyata dengan kultivar lokal lain maupun kultivar IPB 8G. Hal tersebut menandakan bahwa kelima kultivar memiliki luas daun yang hampir sama. Kultivar Timur memiliki luas daun nyata lebih luas dari pada Jatiluhur. Kultivar Jatiluhur memiliki luas daun sebesar $39,98 \mathrm{~cm}^{2}$ yang merupakan kultivar dengan daun tersempit diantara yang lain. 
Tabel 6. Rata-rata luas daun pada fase anakan maksimum dan berbunga 50\%

\begin{tabular}{lcc}
\hline \multirow{2}{*}{ Kultivar } & \multicolumn{2}{c}{ Luas daun pada fase- $\left(\mathrm{cm}^{2}\right)$} \\
\hline Abung & Anakan maksimum & Berbunga $50 \%$ \\
Mayas & $66,95 \mathrm{ab}$ & $56,52 \mathrm{bcd}$ \\
Samarindah & $57,72 \mathrm{ab}$ & $50,46 \mathrm{~cd}$ \\
Timur & $68,51 \mathrm{ab}$ & $73,92 \mathrm{ab}$ \\
Jatiluhur & $73,71 \mathrm{a}$ & $64,59 \mathrm{abc}$ \\
IPB 8G & $39,98 \mathrm{~b}$ & $46,37 \mathrm{~d}$ \\
\hline
\end{tabular}

Keterangan: Angka yang diikuti huruf yang sama pada kolom yang sama tidak berbeda nyata pada Uji Tuckey taraf 5\%; MST = Minggu Setelah Tanam

Hasil pengukuran luas daun pada fase berbunga 50\% menunjukkan bahwa kultivar yang memiliki daun terluas adalah IPB 8 G tetapi tidak berbeda nyata dengan kultivar Samarindah dan Timur. Kultivar yang memiliki luas daun terkecil pada fase berbunga 50\% adalah Jatiluhur dengan luas $46,37 \mathrm{~cm}^{2}$. Hasil uji korelasi menunjukkan terdapat hubungan negatif yang terjadi antara luas daun pada fase anakan maksimum dengan jumlah anakan, yang artinya setiap penambahan jumlah anakan maka rata-rata luas daun pada fase anakan maksimum akan menurun.

Bertambahnya luas daun pada komunitas tanaman disebabkan oleh dua faktor yaitu: 1) meningkatnya jumlah anakan dan 2) meningkatnya luas tiap daun itu sendiri. Peningkatan luas daun pada varietas beranak banyak didominasi oleh faktor pertama, sedangkan dalam varietas beranak sedikit faktor kedua yang lebih mendominasi (Manurung dan Ismunadji, 1988).
Tabel 7 menunjukkan hasil pengukuran warna daun menggunakan alat SPAD meter. Perlakuan kultivar nyata berpengaruh terhadap warna daun tanaman. Hasil pengukuran menunjukkan pada fase anakan maksimum, warna daun dari ke empat kultivar padi lokal nyata berbeda dengan dua kultivar pembanding. Keseluruhan kultivar lokal mengalami gejala kekurangan hara $\mathrm{N}$ sesuai dengan penjelasan dari Dobermann dan Fairhurst (2000), nilai kritis SPAD yang menunjukkan tanaman kekurangan hara $\mathrm{N}$ adalah sebesar 35. Nilai SPAD dari kultivar Jatiluhur dan IPB 8G menunjukkan bahwa keduanya tidak mengalami kekurangan hara $\mathrm{N}$. Terdapat korelasi positif antara warna daun pada fase anakan maksimum dengan persen hampa, bobot 1000 butir, bobot gabah per rumpun juga hasil ubinan. Hal tersebut dapat dikatakan bahwa semakin tinggi nilai SPAD pada hasil pengukuran warna daun fase anakan maksimum, maka hasil dari ke empat komponen produksi diatas juga semakin tinggi.

Tabel 7. Rata-rata warna daun pada fase anakan maksimum dan berbunga 50\%

\begin{tabular}{lll}
\hline \multirow{2}{*}{ Kultivar } & \multicolumn{2}{c}{ Warna daun pada fase- } \\
\cline { 2 - 3 } & Anakan maksimum & Berbunga 50\% \\
\hline Abung & $28,90 \mathrm{~b}$ & $28,10 \mathrm{~b}$ \\
Mayas & $31,78 \mathrm{~b}$ & $29,11 \mathrm{ab}$ \\
Samarindah & $31,16 \mathrm{~b}$ & $30,31 \mathrm{ab}$ \\
Timur & $31,84 \mathrm{~b}$ & $30,99 \mathrm{a}$ \\
Jatiluhur & $36,26 \mathrm{a}$ & $29,80 \mathrm{ab}$ \\
IPB 8G & $38,12 \mathrm{a}$ & $28,21 \mathrm{~b}$ \\
\hline
\end{tabular}

Keterangan: Angka yang diikuti huruf yang sama pada kolom yang sama tidak berbeda nyata pada Uji Tuckey taraf 5\%; MST = Minggu Setelah Tanam

Hasil pengukuran warna daun pada fase berbunga 50\% terlihat bahwa keseluruhan perlakuan kultivar memiliki nilai SPAD dibawah 35 yang artinya keseluruhan kultivar mengalami kekurangan hara N. Wahid (2003) menyatakan bahwa tingkat skala warna daun tanaman padi dipengaruhi oleh populasi tanaman, fase pertumbuhan tanaman, varietas yang digunakan, cara tanam, dan status hara $\mathrm{N}$ dalam tanah.
Nilai SPAD dari daun tanaman kultivar Timur yang paling tinggi diantara yang lain namun tidak berbeda nyata dengan kultivar Mayas, Samarindah dan kultivar Jatiluhur. Menurut Simangunsong (2013) tidak terlihat adanya korelasi antara tingginya nilai SPAD dengan produktivitas tanaman. Hal tersebut juga terjadi dalam penelitian Hambali (2014) yang menyatakan dalam penelitiannya bahwa tidak terdapat korelasi antara nilai SPAD terhadap komponen produktivitas pada 
saat pengukuran warna daun fase berbunga $50 \%$. Nilai SPAD daun kultivar IPB $8 \mathrm{G}$ pada saat berbunga $50 \%$ adalah yang terendah, akan tetapi dari hasil ubinan dan bobot 1000 butir bernas serta bobot gabah per rumpun menunjukkan bahwa produktivitas IPB $8 \mathrm{G}$ yang paling tinggi.

\section{Anakan Produktif, Jumlah Gabah per Malai,} Panjang Malai, Persen Hampa, dan Bobot 1000 Butir

Waktu berbunga antara kultivar lokal dengan kultivar Jatiluhur dan IPB 8G berbeda satu sama lain. Kultivar padi lokal mulai muncul bunga pada saat memasuki umur 14 MST dengan urutan tercepat berturut-turut adalah Abung, Timur, Mayas, dan Samarindah. Analisis sidik ragam menunjukkan bahwa perlakuan kultivar berpengaruh sangat nyata terhadap jumlah anakan produktif, panjang malai, jumlah gabah per malai, persen hampa, dan bobot 1000 butir bernas. Rataan komponen hasil tersebut disajikan dalam Tabel 8.

Tabel 8 menunjukkan bahwa kultivar yang memiliki anakan produktif terbanyak adalah Jatiluhur dan berbeda nyata dengan kultivar lain. Sejalan dengan hasil korelasi yang menunjukkan hubungan positif antara jumlah anakan maksimum dengan jumlah anakan produktif. Hal tersebut menandakan bahwa semakin banyak jumlah anakan maksimum maka semakin banyak juga jumlah anakan produktifnya.

Kultivar IPB 8G memiliki jumlah gabah per malai terbanyak yaitu rata-rata 191,89 butir per malai dan berbeda nyata lebih tinggi dari kultivar Samarindah yang merupakan kultivar dengan jumlah gabah per malai terbanyak kedua setelahnya. Kultivar Samarindah memiliki jumlah gabah per malai rata-rata 148,51 butir per malai. Kultivar yang memiliki jumlah gabah per malai terbanyak ketiga adalah Mayas yaitu 131,43 butir. Jumlah gabah per malai memiliki korelasi positif dengan bobot gabah per rumpun dan ubinan,

Tabel 8. Nilai rataan komponen hasil padi

\begin{tabular}{lcllll}
\hline Kultivar & $\begin{array}{c}\text { Anakan produktif } \\
\text { (batang) }\end{array}$ & $\begin{array}{l}\text { Jumlah gabah per } \\
\text { malai (butir) }\end{array}$ & $\begin{array}{l}\text { Panjang } \\
\text { malai }(\mathrm{cm})\end{array}$ & $\begin{array}{l}\text { Persen } \\
\text { hampa }(\%)\end{array}$ & $\begin{array}{l}\text { Bobot } \\
1000 \mathrm{butir} \\
(\mathrm{g})\end{array}$ \\
\hline Abung & $9,17 \mathrm{~b}$ & $93,89 \mathrm{~d}$ & $18,22 \mathrm{~b}$ & $20,12 \mathrm{bc}$ & $19,89 \mathrm{c}$ \\
Mayas & $9,27 \mathrm{~b}$ & $131,43 \mathrm{bc}$ & $15,59 \mathrm{c}$ & $19,81 \mathrm{bc}$ & $19,51 \mathrm{c}$ \\
Samarindah & $8,00 \mathrm{~b}$ & $148,51 \mathrm{~b}$ & $17,63 \mathrm{~b}$ & $13,39 \mathrm{c}$ & $20,96 \mathrm{c}$ \\
Timur & $7,93 \mathrm{~b}$ & $92,00 \mathrm{~d}$ & $19,63 \mathrm{~b}$ & $25,88 \mathrm{abc}$ & $24,18 \mathrm{~b}$ \\
Jatiluhur & $12,37 \mathrm{a}$ & $126,44 \mathrm{c}$ & $19,25 \mathrm{~b}$ & $31,11 \mathrm{ab}$ & $23,90 \mathrm{~b}$ \\
IPB 8G & $8,40 \mathrm{~b}$ & $191,89 \mathrm{a}$ & $27,17 \mathrm{a}$ & $33,44 \mathrm{a}$ & $29,35 \mathrm{a}$ \\
\hline
\end{tabular}

Keterangan: Angka yang diikuti huruf yang sama pada kolom yang sama tidak berbeda nyata pada Uji Tuckey taraf 5\%; MST = Minggu Setelah Tanam sehingga jumlah gabah per malai yang banyak akan sejalan dengan banyaknya hasil bobot gabah per rumpun dan ubinan.

Panjang malai dari kultivar IPB 8G terpanjang diantara yang lain. Panjang malai dari kultivar Samarindah lebih pendek dibandingkan dengan kultivar IPB 8G, Jatiluhur, Abung dan Timur namun memiliki jumlah gabah per malai terbanyak kedua setelah IPB 8G. Kultivar Timur memiliki panjang malai terpanjang kedua setelah IPB 8G akan tetapi jumlah gabah malai tersedikit diantara yang lain. Hal tersebut terbukti dengan tidak adanya korelasi antara panjang malai dengan jumlah gabah per malai disebabkan bentuk dan susunan malai yang berbeda. Bentuk malai yang berbeda antar kultivar dapat dipengaruhi oleh faktor genetik. Kultivar yang memiliki bentuk malai yang tidak terlalu panjang namun memiliki jumlah gabah banyak adalah Mayas dan Samarindah. Hairmansis et al. (2005) menyatakan, bentuk malai yang lebat bermanfaat dalam program perakitan varietas padi tipe baru. Sehingga dua kultivar lokal tersebut berpotensi untuk dikembangkan

Persentase gabah hampa per malai per rumpun tanaman terkecil urutan pertama adalah kultivar Samarindah yaitu sebesar $13,39 \%$ dan urutan kedua adalah kultivar Mayas yaitu 19,81\%. Kultivar Samarindah memiliki jumlah gabah per malai yang kedua terbanyak serta presentase gabah hampa per malai yang terkecil jika dibandingkan dengan kultivar IPB 8G yang merupakan kultivar dengan jumlah gabah per malai terbesar, kultivar ini berpotensi besar untuk dikembangkan dalam perakitan varietas padi tipe baru yang dapat diunggulkan sejalan dengan pendapat Abdullah et a. (2008), padi tipe baru yang berpotensi hasil tinggi umumnya harus mempunyai sifat-sifat baik dua diantaranya adalah jumlah gabah per malai 150-250 butir dan persentase gabah bernas $85-95 \%$ (presentase gabah hampa 5-15\%). 
Kultivar IPB 8G yang memiliki jumlah gabah terbanyak diantara yang lain memiliki persentase gabah hampa yang besar yaitu rata-rata $33,44 \%$. Hal tersebut diduga karena kultivar IPB 8G mengalami kerebahan pada saat 2 minggu setelah tanaman berbunga sehingga mengakibatkan terganggunya proses pengisian biji yang menyebabkan gabah hampa. Tanaman yang rebah menyebabkan terganggunya proses pengangkutan hara mineral dan fotosintat, selain itu pergelaran daun-daun menjadi tidak beraturan dan saling menaungi dan akhirnya menghasilkan gabah hampa (Manurung dan Ismunadji, 1988).

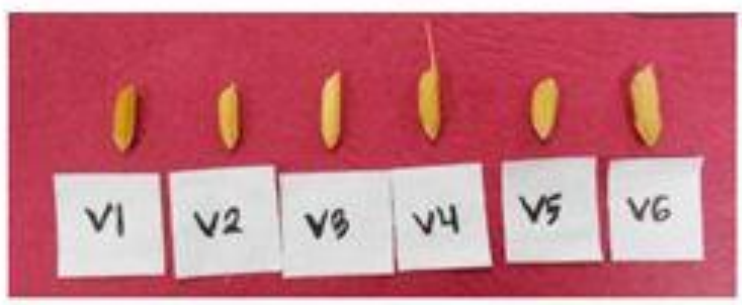

V1=Abung, V2=Mayas, V3=Samarindah, V4=Timur, V5= Jatiluhur, V6=IPB 8G

Gambar 2. Perbedaan bentuk bulir padi pada percobaan pertumbuhan dan produksi beberapa padi lokal Kalimantan

Data bobot 1000 butir bernas dari hasil pengamatan memperlihatkan bahwa kultivar IPB 8G memiliki bobot terbesar yaitu 29,35 gram dan berbeda nyata lebih besar dari ke empat kultivar padi lokal Kalimantan dan Jatiluhur. Dari ke empat kultivar padi lokal Kalimantan, kultivar Timur yang memiliki bobot 1000 butir bernas terbesar yaitu 24,18 gram dan tidak berbeda nyata dengan Jatiluhur. Hal tersebut dapat dikarenakan bentuk dan ukuran bulir padi antara keseluruhan kultivar berbeda satu dengan yang lain seperti yang terlihat pada Gambar 2.

\section{Bobot Gabah per Rumpun dan Hasil Ubinan}

Analisis ragam menunjukkan bahwa perlakuan kultivar nyata berpengaruh terhadap bobot gabah per rumpun. Tabel 9 memperlihatkan bahwa bobot gabah per rumpun dari ke empat kultivar lokal Kalimantan tidak berbeda nyata satu sama lain, tetapi berbeda nyata lebih kecil dibandingkan dengan kultivar IPB 8G.

Kultivar yang memiliki bobot gabah per rumpun tertinggi diantara kultivar lokal lain adalah Samarindah dengan bobot rata-rata 21,34 gram sedangkan kultivar IPB $8 \mathrm{G}$ memiliki ratarata bobot gabah per rumpun tertinggi dari keseluruhan perlakuan kultivar yaitu 33,89 gram. Hasil uji korelasi menunjukkan bahwa terdapat korelasi yang positif antara bobot gabah per rumpun dengan hasil ubinan yang artinya semakin tinggi bobot gabah per rumpun maka hasil ubinan juga akan tinggi.
Tabel 9. Nilai rataan bobot gabah pe rumpun

\begin{tabular}{lc}
\hline Kultivar & Bobot gabah per rumpun (gram) \\
\hline Abung & $14,71 \mathrm{~b}$ \\
Mayas & $19,78 \mathrm{~b}$ \\
Samarindah & $21,34 \mathrm{~b}$ \\
Timur & $15,04 \mathrm{~b}$ \\
Jatiluhur & $26,78 \mathrm{ab}$ \\
IPB 8G & $33,89 \mathrm{a}$ \\
\hline Keterangan : & Angka yang diikuti huruf yang sama pada \\
& kolom yang sama tidak berbeda nyata pada \\
& Uji Tuckey taraf 5\%; MST = Minggu \\
& Setelah Tanam
\end{tabular}

Ubinan yang digunakan memiliki ukuran $1 \times 1 \mathrm{~m}$ dengan total jumlah rumpun adalah 30 rumpun. Hasil analisis ragam pada taraf $5 \%$ menunjukkan bahwa perlakuan kultivar memberikan pengaruh sangat nyata terhadap hasil ubinan tanaman padi. Hasil uji lanjut komponen hasil ubinan disajikan dalam Tabel 10.

Tabel 10. Nilai rataan hasil ubinan padi

\begin{tabular}{lc}
\hline Kultivar & Ubinan (ton per ha) \\
\hline Abung & $3,86 \mathrm{c}$ \\
Mayas & $4,47 \mathrm{c}$ \\
Samarindah & $5,18 \mathrm{bc}$ \\
Timur & $3,88 \mathrm{c}$ \\
Jatiluhur & $7,01 \mathrm{ab}$ \\
IPB 8G & $8,57 \mathrm{a}$ \\
\hline Keterangan : & Angka yang diikuti huruf yang sama pada \\
& kolom yang sama tidak berbeda nyata pada \\
& Uji Tuckey taraf 5\%; MST = Minggu \\
& Setelah Tanam
\end{tabular}

Tabel 10 menunjukkan produktivitas masing-masing kultivar yang diuji. Produktivitas IPB 8G dilihat dari hasil ubinan yaitu sebesar 8,57 ton per ha nyata berbeda lebih tinggi dari pada kultivar lainnya, hal tersebut diduga karena 
pengaruh dari jumlah gabah per malai dan bobot 1000 butir bernas yang lebih tinggi dari pada kultivar lokal.

Produktivitas dari kultivar padi lokal Kalimantan terbesar adalah kultivar Samarindah yaitu 5,18 ton per ha kemudian diikuti kultivar Mayas (4,47 ton per ha), Timur (3,88 ton per ha) dan Abung (3,86 ton per ha). Kultivar Samarindah memiliki hasil ubinan tertinggi diantara kultivar lain diduga karena memiliki jumlah gabah per malai terbanyak dan persentase gabah hampa terkecil.

\section{KESIMPULAN}

Hasil penelitian menunjukkan bahwa terdapat perbedaan komponen pertumbuhan dan produksi antara kultivar lokal Kalimantan dengan kultivar pembanding yaitu Jatiluhur dan IPB 8G. Kultivar yang memiliki produktivitas tertinggi hingga ter rendah berturut-turut adalah IPB $8 \mathrm{G}$ (8,57 ton per ha), Jatiluhur (7,01 ton per ha), Samarindah (5,18 ton per ha), Mayas (4,47 ton per ha), Timur (3,88 ton per ha), serta Abung (3,86 ton per ha). Kultivar lokal Samarindah dan Mayas memiliki persentase gabah hampa terkecil dari keseluruhan perlakuan kultivar.

\section{DAFTAR PUSTAKA}

Abdullah,B., S. Tjokrowidodo, dan Sularjo. 2008. Perkembangan dan prospek perakitan padi tipe baru di Indonesia. Jurnal Litbang Pertanian. $27: 1-9$

Anhar, R., H. Erita. dan Efendi. 2016. Pengaruh dosis pupuk urea terhadap pertumbuhan dan produksi plasma nutfah padi lokal asal Aceh. Jurnal Kawista. 1(1): 30-36

[BPS] Badan Pusat Statistik. 2015. Impor Beras Menurut Negara Asal Utama, 2000-2014. [Internet] [diunduh 2015 Maret 8] Tersedia pada http://www.bps.go.id/

Bustami, Sufardi dan Bakhtiar. 2012. Serapan hara dan efisiensi pemupukan phosfat serta pertumbuhan padi varietas lokal. Jurnal Manajemen Sumberdaya Lahan. 1 (2): 159170.

Cepy dan W. Wayan. 2011. Pertumbuhan dan hasil tanaman padi (Oryza sativa L.) di media vertisol dan entisol pada berbagai teknik pengaturan air dan jenis pupuk. Jurnal Crop Agro 4(2): 49-56.
De datta S.K. 1975. Unpland rice around the world: 1-11. In IRRI (ed). Major Research in Unpland Rice. IRRI. Los Banos.

Dobermann, A. dan T. Fairhurst. 2000. Rice: Nutrient disordes and nutrient management. Potash and Phospate Institute: Canada (US).

Gomez, K.A., A.A. Gomez. 2007. Prosedur Statistik untuk Penelitian Pertanian. Sjamsuddin E, Baharsjah JS, penerjemah. Jakarta (ID): UI Press Terjemahan dari: Statistical Procedures for Agriculture Research.

Hairmansis, A., A. Hajrial, Trikoesoemaningtyas. dan Suwarno. 2005. Evaluasi daya pemulih kesuburan padi lokal dari kelompok tropikal japonica. Buletin Agronomi. 33 (3): 1-6.

Hambali, A. 2014. Evaluasi produktifitas beberapa varietas padi. skripsi. Institut Pertanian Bogor. Bogor.

[IRRI] International Rice Research Institute. 2002. Rice standard evaluation system. [Internet] [diunduh 2016 Februari 11] Tersedia pada http://www.knowledgebang.irri.org

Kaltimprov. 2013. Ramai-ramai kembangkan padi gunung unggul di Kaltim. [Internet] [diunduh 2015 November 2] Tersedia pada http://wiek.kaltimprov.go.id/read/news/201 3/1108/ramai-ramai-kembangkan-padigunung-unggul-di-kaltim-html.

Kurniasih, Taryono, dan Tokidjo. 2008. Keragaman beberapa varietas padi pada kondisi cekaman kekeringan dan salinitas. Jurnal Ilmu Pertanian. 15 (1): 49-58.

Mahananto, S., C.F. Sutrisno dan Ananda. 2009. Faktor-faktor yang mempengaruhi produksi padi studi kasus di kecamatan nogosari, boyolali, jawa tengah. WACANA. 12 (1):1411-0199.

Manurung, S.O. dan M. Ismunadji. 1988. Padi: Morfologi dan fisiologi padi. Badan Penelitian dan Pengembangan Pertanian, Pusat Penelitian dan Pengembangan Tanaman Pangan. Bogor.

Nasution, S. 2015. Uji daya hasil galur padi (Oryza sativa L.) harapan IPB dengan dua 
varietas pembanding. skripsi. Institut Pertanian Bogor. Bogor.

Nazirah, L. dan B.S.J. Damanik. 2015. Pertumbuhan dan hasil tiga varietas padi gogo pada perlakuan pemupukan. Jurnal Floratek. 10:54-60

Nurhasanah, dan W. Sunaryo. 2015. Keragaman genetik padi lokal Kalimantan Timur. Pros Sem Nas Masy Biodiv Indon. 1 (7).

Prawiranata, W., S. Harran. dan P. Tjondronegoro. 1988. Dasar-Dasar Fisiologi Tumbuhan. Departemen Botani Fakultas Pertanian IPB. Bogor. 313 hal. Purwono dan Purnamawati H. 2007. Budidaya 8 Jenis Tanaman Pangan Unggul. Penebar Swadya, Jakarta.

Simangunsong, M. 2013. Analisis Produktivitas beberapa tipe padi. skripsi. Institut Bogor. Bogor. Subroto H.G. 2002. Evaluasi lanjutan enam genotipe padi gogo asal Kalimantan Timur terhadap cekaman aluminium. skripsi. Institut Pertanian Bogor. Bogor

Syahri dan R.U. Somantri. 2013. Respon pertumbuhan tanaman padi terhadap rekomendasi pemupukan PUTS dan KATAM hasil litbang pertanian dilahan rawa Sumatra Selatan. Jurnal Lahan Suboptimal. 2 (2): 170-180.

Wahid, A.S. 2003. Peningkatan efisiensi pupuk nitrogen pada padi sawah dengan metode bagan warna daun. Jurnal Litbang Pertanian. 22(4).

Yunanda, A.P., A.R. Fauzi dan A. Junaedi. 2014. Pertumbuhan dan produksi padi varietas jatiluhur dan IR64 pada sistem budidaya gogo dan sawah. Bul. Agrohorti 1 (4) : 18 25 . 